\title{
ANALISA LAPORAN KEUANGAN PRODUK SIMPANAN PADA KOPERASI KREDIT
}

\author{
Yuliana.F. Lilistian \\ Fakultas Ilmu Sosial dan Ilmu Politik Universitas Kapuas Sintang \\ Jln. YC. Oevang Oeray Nomor 92 Baning Kota Sintang \\ Email: yulianaunka@gmail.com
}

\begin{abstract}
Abstrak : Laporan keuangan sebagai pertanggungjawaban pengurus atau pengelola koperasi kredit kepada anggota, para kreditur seperti Puskopdit, Inkopdit dan pemerintah tentang perkembangan dan kondisi keuangan koperasi kredit harus disusun secara berkala. Laporan keuangan yang dibuat oleh pengurus atau pengelola koperasi kredit, untuk menghasilkan angka laporan sesuai dengan persepsi mereka. Metode dalam penelitian ini menggunakan metode penelitian deskriptif.
\end{abstract}

Kata Kunci : Analisa, Laporan Keuangan

Laporan keuangan dapat dengan jelas memperlihatkan gambaran kondisi keuangan dari perusahaan. Laporan keuangan yang merupakan hasil dari beberapa kegiatan operasi normal perusahaan akan memberikan memberikan informasi keuangan yang berguna bagi lingkungan internal dalam perusahaaan itu sendiri maupun lingkungan yang ada di luar perusahaan, oleh karena itu untuk mengetahui kinerja laporan keuangan memerlukan suatu analisis, analisis-analisis inilah yang harus dipahami oleh manajemen perusahaan untuk mengevaluasi kinerja perusahaan ataupun sebagai investor jika menginvestasikan harta terhadap suatu perusahaan. Laba atau keuntungan merupakan ukuran bagi keberhasilan dari suatu operasi perusahaan. Perusahaan dikatakan sehat apabila mempunyai kemampuan yang cukup besar dalam menghasilkan laba sepanjang hidupnya, serta hal yang tidak boleh diabaikan yakni kemampuan yang cukup besar pula dalam memenuhi semua kewajiban keuangannya. Jika faktor tersebut mampu dilaksanakan dengan baik oleh manajemen perusahaan selama berlangsungnya kegiatan operasi, maka perjalanan hidup perusahaan itu dapat dipertahankan dan dikembangkan secara optimal sesuai dengan tujuan dan sasaran yang telah ditetapkan.

Koperasi Kredit yang sering juga disebut "CreditUnion" adalah koperasi yang mempunyai usaha tunggal, yakni simpan-pinjam sebagai usaha atau bisnis utamanya. Koperasi kredit ini biasanya muncul atas prakarsa dan mufakat sekelompok orang yang merasa mempunyai kesamaan kebutuhan dan kepentingan untuk menggerakkan suatu modal bersama, terutama yang berasal dari simpanan untuk dipinjamkan diantara sesama mereka, dengan tingkat bunga yang memadai sesuai dengan kesepakatan bersama pula. Pinjaman dapat diberikan atas dasar keperluan darurat, usaha produktif (niaga atau investasi), atau untuk keperluan kesejahteraan para anggota. Sama seperti organisasi pada umumnya, Koperasi Kredit Indonesia harus memiliki informasi. Informasi bisa berupa apa saja, jumlah anggota, jumlah set, jumlah hutang dan piutang, dan masih banyak lagi. Oleh karena itu sistem informasi yang harus kita miliki adalah, sistem akuntansi keuangan koperasi kredit. Sistem akuntansi Koperasi Kredit terdiri dari serangkaian kegiatan manusia yang melakukan aturan-aturan, alat-alat, dokumen-dokumen yang berfungsi mengelola informasi keuangan agar siap digunakan setiap saat oleh pihak-pihak yang berkepentingan dengan pengelolaan organisasi tersebut dalam pengambilan keputusan.

Laporan keuangan sebagai pertanggungjawaban pengurus atau pengelola koperasi kredit kepada anggota, para kreditur seperti Puskopdit, Inkopdit dan pemerintah tentang perkembangan dan kondisi keuangan koperasi kredit harus disusun secara berkala. Laporan keuangan yang dibuat oleh pengurus atau pengelola koperasi kredit, untuk menghasilkan angka laporan sesuai dengan persepsi mereka. Induk Koperasi Kredit Indonesia telah menyusun sistem akuntansi koperasi kredit (SAKK) dan telah diperkenalkan kepada seluruh koperasi kredit di Indonesia. Berdasarkan SAKK tersebut telah memenuhi Standar Akuntansi Koperasi No. 27 yang dikeluarkan oleh Ikatan Akuntan Indonesia (IAI). Dalam SAK No. 27 telah diatur tentang standar laporan keuangan koperasi, penyajian pendapatan, beban, aktiva, kewajiban dan kekayaan bersih. Sebagai bagian dari suatu sub sistem atau sistem maka dalam mengemban fungsi tersebut Sistem Keuangan Koperasi Kredit harus berinteraksi dengan sub sistem-sub sistem yang lain dalam organisasi gerakan koperasi kredit, yaitu sistem 
pengerahan dana (simpanan), sistem penyaluran dana (pinjaman), di samping sub sistem yang lain, seperti sistem penggajian dan pengupahan.

Pada umumnya, proses akuntansi keuangan ini terdiri dari tiga bagian yang besar : masukan (input) yang beruapa transaksi-transaksi; proses, di mana terjadi pengolahan transaksi serta keluaran (output) yang berupa laporan keuangan. Tujuan laporan koperasi adalah mengetahui manfaat yang diperoleh anggota, mengetahui prestasi keuangan koperasi selama satu periode dengan sisa hasil usaha. Manfaat keanggotaann koperasi dapat diukur dengan mengetahui sumber daya ekonomis yang dimiliki koperasi, kewajiban dan kekayaan bersih serta adanya pemisahan antara anggota dan bukan anggota dan mengetahui informasi penting lainnya yang mungkin sedang mempengaruhi likuiditas dan solvabilitas koperasi. Laporan keuangan koperasi meliputi: neraca, perhitungan hasil usaha, laporan arus kas dan catatan atas laporan keuangan, serta laporan perubahan kekayaan bersih sebagai laporan keuangan tambahan. Pendapatan yang diperoleh dari penjualan produk atau menyerahkan jasa kepada anggota dilaporkan secara terpisah pada perhitungan hasil usaha sebagai penjualan kepada anggota atau pendapatan dari anggota. Laporan keuangan koperasi bukan merupakan laporan keuangan konsolidasi dari koperasi-koperasi. Dalam hal terjadi penggabungan dua atau lebih koperasi menjadi satu badan hukum koperasi, maka dalam penggabungan tersebut perlu memperhatikan nilai aktiva bersih yang riil dan bilamana perlu melakukan penilaian kembali. Koperasi mempunyai perusahaan dan unit-unit usaha yang berada di bawah pengelolaan, maka disusun laporan keuangan konsolidasi atau laporan keuangan gabungan. Proses penyusunan laporan keuangan tidak luput dari penggunaan taksiran dan berbagai pertimbangan, dan hanya melaporkan informasi yang bersifat material. Laporan keuangan koperasi kredit bersifat konservatif dalam menghadapi ketidakpastian. Laporan keuangan lebih menekankan makna ekonomis suatu peristiwa/ transaksi daripada bentuk hukumnya (formalitas). Pada koperasi kredit, laporan keuangan disusun dengan menggunakan istilah-istilah teknis dan pemakai laporan diasumsikan memahami bahasa teknis akuntansi dan sifat dari informasi yang dilaporkan. Adanya pelbagai alternatif metode akuntansi yang dapat digunakan menimbulkan variasi dalam pengukuran sumber-sumber ekonomis dan tingkat kesuksesan antar perusahaan. Informasi yang bersifat kualitatif dan fakta yang tidak dapat dikualifikasikan umumnya diabaikan.

Koperasi Kredit Bina Masyarakat Sekadau didirikan pada Tanggal 1 Mei 2014 dengan Asset sekitar 10.656.337.000 juta, anggota 970-an orang serta di kelola oleh 4 orang karyawan. Visi yang dimiliki oleh Koperasi Kredit Bina Masyarakat Sekadau yaitu menjadi Koperasi Kredit yang tangguh, besar, aman dan dicintai masyarakat. Produk yang dimiliki oleh Koperasi Kredit Bina Masyarakat terbagi dua, yaitu produk simpanan dan produk pinjaman.

Produk simpanan terdiri dari simpanan saham dan simpanan non saham. Pada simpanan saham terdiri dari simpanan pokok dan simpanan wajib yang pengertiannya adalah simpanan keanggotaan dengan sistem balas jasa atau deviden 1 tahun sekali. Sementara, simpanan non saham terdiri dari : Simpanan Sejahtera Anggota (SSA), Simpanan taktis (sintak), Simpanan Masa Tua (Simatu), Tabungan Bea Siswa (TAWA), Simpanan Perkebunan (Sibun), Simpanan Sukarela Berjangka (Sisuka), dan Tabungan Untuk Anak Sekolah (Tunas). Untuk melihat perkembangan Simpanan Tabungan yang ada di Koperasi Kredit Bina Masyarakat dapat dilihat pada tabel 1.1 berikut.

Tabel 1 Data Transaksi dan Jumlah Penabung Produk Simpanan Saham dan Non Saham pada Bulan Mei dan Juni 2019 Koperasi Kredit Bina Masyarakat Cabang Sekadau

\begin{tabular}{|c|c|c|c|c|}
\hline \multirow{2}{*}{ Jenis Simpanan } & \multicolumn{2}{|r|}{ Bulan Mei } & \multicolumn{2}{|r|}{ Bulan Juni } \\
\hline & Anggota & Transaksi & Anggota & Transaksi \\
\hline Simpanan Wajib & 228 & Rp. $\quad 502.158 .000,-$ & 302 & Rp. $\quad 512.133 .000,-$ \\
\hline Simpanan Pokok & 757 & Rp. $\quad 595.578 .000,-$ & 685 & Rp. 602.293.800,- \\
\hline SSA & - & Rp. 4.941.184.201,- & - & Rp. 5.028.885.412,- \\
\hline SINTAK & 198 & Rp. $\quad 421.178 .391,-$ & 203 & Rp. $\quad 407.087 .522,-$ \\
\hline SISUKA & - & - & - & - \\
\hline TAWA & 36 & $82.379 .901,-$ & 36 & 78.169.191,- \\
\hline SIMATU & 13 & $42.186 .901,-$ & 13 & $41.894 .211,-$ \\
\hline SIBUN & 41 & Rp. $\quad 105.943 .759,--$ & 40 & Rp. $\quad 106.893 .724,-$ \\
\hline TUNAS & 353 & Rp. $\quad 240.379 .905,-$ & 360 & Rp. $235.180 .030,-$ \\
\hline Jumlah & & Rp. 6.930.989.033,- & & Rp. 7.012.536.830,- \\
\hline
\end{tabular}

Sumber : Koperasi Kredit Bina Masyarakat Cabang Sekadau, Juni 2019 
Berdasarkan pada tabel 1 diatas bahwa terlihat data transaksi dan jumlah penabung produk simpanan saham dan non saham pada Bulan Mei dan Juni 2019 Koperasi Kredit Bina Masyarakat Cabang Sekadau menunjukkan peningkatan sebesar Rp. 81.547.797,- (delapan puluh satu juta lima ratus empat puluh tujuh ribu tujuh ratus sembilan puluh tujuh rupiah). Dengan melakukan analisis keuangan diharapkan dapat mengetahui transaksi, kewajiban dan kekayaan bersih, dalam satu periode dengan pemisahan antara yang berkaitan dengan anggota dan non anggota. Selain, mengetahui informasi penting lainnya yang mungkin mempengaruhi keadaan keuangan jangka pendek dan jangka panjang(likuiditas dan solvabilitas), serta prestasi koperasi dalam melayani anggota.

Analisis laporan keuangan adalah suatu proses penelitian laporan keuangan beserta unsurunsurnya yang bertujuan untuk mengevaluasi dan memprediksi kondisi

keuangan perusahaan atau badan usaha dan juga mengevaluasi hasilhasil yang telah dicapai perusahan atau badan usaha pada masa lalu dan mas sekarang. Analisis laporan keuangan dilakukan pada dasarnya untuk mengetahui apakah keadaan keuangan, hasil usaha kemajuan keuangan perusahaan memuaskan atau tidak memuaskan. Analisis dilakukan dengan mengukur hubungan antar unsur-unsur laporan keuangan dan bagaimana perubahan unsur-unsur itu dari tahun ke tahun dan untuk mengetahui arah perkembangannya.Laporan keuangan yang dibuat oleh bagian akunting secara periodik, biasanya telah mengikuti standar yang ditetapkan oleh Standar Akuntansi Keuangan (SAK) dan berlaku secara umum. Artinya, setiap perusahaan wajib mengikuti kaidah/aturan. Namun demikian, bagi perusahaan publik, laporan keuangan ini harus diaudit oleh akuntan public untuk menjamin konsistensi sistem yang digunakan sehingga perkembangan kinerja perusahaan relatif lebih mencerminkan kondisi sebenarnya.

Analisis laporan keuangan terdiri dari dua kata, yaitu "analisis" dan "laporan keuangan", kata "analisis" didefinisikan sebagai "penguraian suatu pokok atas berbagai bagiannya dan penelaahan bagian itu sendiri serta hubungan antar bagian untuk memperoleh pengertian yang tepat dan pemahaman arti keseluruhan". Analisis laporan keuangan seperti yang dikemukakan oleh Prastowo dan Juliaty (2008:56) Analisis laporan keuangan tidak lain merupakan suatu proses untuk membedah laporan keuangan ke dalam unsur- unsurnya, menelaah masing- masing unsur tersebut, dan menelaah hubungan diantara unsur- unsur tersebut, dengan tujuan untuk memperoleh pengertian dan pemahaman yang baik dan tepat atas laporan keuangan itu sendiri. Analisis laporan keuangan dituntut mempunyai pengertian yang cukup tentang unsur- unsur yang membentuk laporan keuangan. Analisis keuangan adalah suatu analisis ratio keuangan, analisis kelemahan dan kekuatan di bidang finansial di mana analisis ini diperuntukkan dalam menilai prestasi manajemen di masa lalu dan prospeknya di masa akan datang. Menurut Sartono (2008:113) "Untuk melakukan analisis ini dapat dilakukan dengan membandingkan prestasi suatu periode dibanding dengan periode sebelumnya sehingga diketahui adanya kecenderungan selama periode tertentu. Berdasarkan pendapat di atas, analisis laporan keuangan merupakan suatu proses untuk mengetahui seberapa baik kinerja perusahaan dilihat dari unsur- unsur yang ada dalam laporan keuangan, sehingga hasil analisis itu dapat digunakan untuk menentukan keputusan yang akan diambil oleh perusahaan di masa yang akan datang.

Menurut Sucipto (2003:34), pengertian kinerja keuangan adalah "ukuran tertentu yang dapat mengukur keberhasilan suatu perusahaan dalam menghasilkan laba." Salah satu untuk mengetahui kesehatan manajemen keuangan perusahaan. Maka yang harus dilakukan adalah dengan melihat kinerja keuangan perusahaan dari laporan keuangan perusahaan tersebut. Kinerja keuangan adalah suatu analisis yang dilakukan untuk melihat sejauhmana suatu perusahaan telah melaksanakan dengan menggunakan aturan-aturan pelaksanaan keuangan secara baik dan benar. Adapun tahap-tahap dalam menganalisis kinerja keuangan perusahaan, menurut pendapat Fahmi (2011:2) ada 5 (lima) tahap dalam menganalisis kinerja keuangan suatu perusahaan secara umum, yaitu :1) Melakukan review terhadap data laporan keuangan, 2) Melakukan perhitungan, 3) Melakukan perbandingan terhadap hasil hitungan yang telah diperoleh, 4) Melakukan penafsiran (interpretasi) terhadap berbagai permasalahan yang ditemukan, dan 5) Mencari dan memberikan pemecahan masalah (solution) terhadap berbagai permasalahan yang ditemukan.

Laporan keuangan yang disusun secara baik dan akurat dapat memberikan gambaran keadaan yang nyata mengenai hasil atau prestasi yang telah dicapai oleh suatu perusahaan selama kurun waktu tertentu, keadaan inilah yang digunakan untuk menilai kinerja keuangan. Berdasarkan prinsip-prinsip manajemen, bahwa pengelolaan sebuah organisasi harus menentukan indikator tertentu untuk mengukur tingkat keberhasilan atau kinerja dan apakah tujuan telah tercapai. Pemrosesan transaksi-transaksi menurut Standar Akuntansi Keuangan Koperasi No 27 (2009:6), mengikuti suatu daur akuntansi keuangan, yang berlangsung secara bertahap dan tahapan tersebut mencakup kegiatan-kegiatan berikut ini :1) Perekaman transaksi ke dalam dokumen-dokumen pendukung dan atau bukti-bukti pembukuan, 2) 
Pencatatan transaksi-transaksi secara berurutan (kronologis) dalam jurnal (buku harian) atau memorial, 3) Pengelompokan transaksi secara sitematis dan berpedoman pada suatu bagan perkiraan-perkiraan buku besar yang besar yang bersangkutan, 4) Pencatatan transaksi secara terinci ke dalam buku-buku pembantu/tambahan, sesuai dengan kebutuhan akan informasi yang perlu dijelaskan secara lengkap dan 5) Pengikhtisaran transaksi (sebagai kertas kerja) dalam neraca lajur di atas secara singkat dan dalam neraca saldo.

Hasil akhir dari proses yang berlangsung dalam sistem akuntansi keuangan itu adalah laporan, baik berupa laporan keuangan yang terdiri dari Neraca, Perhitungan Sisa hasil Usaha, Laporan Perubahan Posisi Keuangan, Laporan Perubahan Kekayaan Bersih maupun lain yang diperlukan terutama oleh pengelola organisasi tersebut dalam mengendalikan kegiatan usaha. Sejarah koperasi lahir pada permulaan abad ke-19 sebagai suatu reaksi terhadap sistem perekonomian kapitalisme di Negara-negara Eropa. Sistem ekonomi ini bersendi pada kebebasan individu untuk mencari keuntungan sebanyak mungkin. Akibatnya kelompok-kelompok tertentu yakni kaum kapitalis, menguasai kehidupan masyarakat luas. Mereka hidup berlebihan, sedang masyarakat yang tidak memiliki modal makin tertindas. Pada saat itulah tumbuh aliran kebersamaan yang menetang aliran individualisme ini dengan asas kebersamaan untuk meningkatkan kesejahteraan bersama. Bentuk kerjasama ini melahirkan suatu perkumpulan yang dinamakan koperasi.

Dalam Undang-undang Nomor 25 Tahun 1992 tentang perkoperasian, koperasi diartikan sebagai badan usaha yang beranggotakan orangorang atau badan hukum koperasi dengan melandaskan kegiatannya berdasarkan prinsip koperasi sekaligus sebagai gerakan ekonomi rakyat yang berdasarkan atas asas kekeluargaan. Hal tersebut menjelaskan dalam koperasi harus ada prinsip-prinsip koperasi sebagai landasan dalam melaksanakan kegiatan perkoperasian tersebut. Yang paling penting dalam pengertian ini adalah bahwa koperasi merupakan badan usaha yang berdiri atas asas kekeluargaan, berbeda dengan badan usaha lain, yang melandasi kegiatan usahanya hanya untuk mencari laba. Menurut Pernyataan Standar Akuntansi Keuangan No 27 (2009:27) pengertian koperasi adalah : Badan usaha yang mengorganisir pemanfaatan dan pendayagunaan sumber daya ekonomi para anggotanya atas dasar prinsip-prinsip koperasi dan kaidah usaha ekonomi untuk meningkatkan taraf hidup anggota pada khususnya dan masyarakat daerah kerja pada umumnya, dengan demikian merupakan gerakan ekonomi rakyat dan soko guru perekonomian nasional. Menurut Moh.Hatta dalam
Soemarsono (2003:3), koperasi didirikan sebagai persekutuan kaum yang lemah untuk membela keperluan hidupnya. Mencapai keperluan hidupnya dengan ongkos yang semurah-murahnya, itulah yang dituju. Pada koperasi di dahulukan keperluan bersama, bukan keuntungan. Masih dalam buku yang sama, Soemarsono (2003:3), menjelaskan menurut International Labour Organization (ILO), pengertian koperasi adalah sebagai berikut: koperasi adalah suatu perkumpulan orang, biasanya yang memiliki kemampuan ekonomi terbatas, yang melalui suatu bentuk organisasi perusahaan yang diawasi secara demokratis, masing-masing memberikan sumbangan setara terhadap modal yang diperlukan, dan bersedia menanggung resiko serta menerima imbalan yang sesuai dengan usaha yang mereka lakukan.

Tujuan koperasi Indonesia dalam Undangundang No 17 Tahun 2012 pasal 3, adalah memajukan kesejahteraan anggota pada khususnya dan masyarakat pada umumnya serta ikut membangun tatanan perekonomian nasional dalam rangka mewujudkan masyarakat yang maju, adil, dan makmur berlandaskan Pancasila dan UUD 1945. Dari tujuan tersebut, koperasi dapat digolongkan menjadi beberapa jenis, berdasarkan kepentingan anggota dan usaha utamanya, koperasi di golongkan menjadi empat jenis, yaitu: 1) Koperasi konsumen, yaitu koperasi yang anggotanya para konsumen akhir atau pemakai barang dan jasa. Tujuan dari koperasi ini adalah agar anggotanya dapat membeli barang dengan kualitas baik dan dengan harga yang layak. 2) Koperasi produsen, yaitu koperasi yang anggotanya adalah rumah tangga atau perusahaan yang menghasilkan dan memasarkan atau jasa. Kegiatan utama koperasi ini adalah menyediakan, mengoprasikan atau mengelola sarana produksi bersama. 3) Koperasi simpan pinjam, yaitu koperasi yang usaha utamanya adalah menyediakan jasa menyimpan dan meminjamkan dana bagi para anggotanya, dan 4) Koperasi pemasaran, yaitu koperasi yang anggotanya para produsen atau pemilik barang atau penyedia jasa dan kegiatan atau usaha utamanya adalah melakukan pemasaran bersama.

Berdasarkan hierarki organisasinya dalam Undang-undang No 17 Tahun 2012 pasal 5, koperasi digolongkan menjadi: 1) Koperasi primer, yaitu koperasi yang anggotanya orang-orang yang memiliki kesamaan kepentingan ekonomi dan melakukan kegiatan usaha yang langsung melayani para anggotanya tersebut, 2) Koperasi sekunder, yaitu koperasi yang anggotanya badan-badan hukum koperasi yang karena kesamaan kegiatan ekonominya mereka bergabung untuk tujuan efisiensi dan kelayakan ekonomis dalam rangka melayani para anggotanya. 
Semakin berkembangnya koperasi dewasa ini, membuat di perlukannya suatu standar dalam pengelolaan koperasi khususnya dalam penyusunan laporan keuangan. Kondisi inilah yang kemudian melatarbelakangi munculnya Standar Akuntansi Keuangan Koperasi No 27 Tahun 2009. Konsep Dasar Akuntansi Koperasi Kredit tidak berbeda dengan prinsip Akuntansi di Indonesia, menurut Standar Akuntansi Keuangan Koperasi No 27 (2009:7): 1) Kesatuan Akuntansi, 2) Kesinambungan, 3) Periode Akuntansi atau Periodisasi, 4) Pengukuran Dalam Nilai Uang, 5) Harga Pertukaran, 6) Penetapan Pendapatan dan Beban.

Perbedaan koperasi dengan perusahaan lainnya bukan hanya dapat dilihat melalui orientasi bisnisnya saja, namun dapat juga terlihat melalui laporan keuangan yang disajikannya. Dalam PSAK No 27 (2007:27,9) disebutkan bahwa laporan keuangan koperasi itu terdiri atas : Neraca, Perhitungan Hasil Usaha, Laporan Arus Kas, Laporan Promosi Ekonomi Anggota.

Pernyataan Standar Akuntansi Keuangan Koperasi Nomor 27 telah di rancang sebagai standar dalam penyajian laporan keuangan koperasi, sehingga sudah sewajarnya koperasikoperasi, khususnya koperasi yang cukup berprestasi seperti Koperasi Kredit sudah menggunakan standar tersebut sebagai acuan dalam penyusunan laporan keuangannya. Setiap perusahaan memiliki laporan keuangan yang dibuat oleh manajemen dengan tujuan untuk memberikan informasi tentang posisi, kinerja keuangan suatu perusahaan dan perubahan posisi keuangan suatu perusahaan yang terjadi selama tahun buku bersangkutan yang bermanfaat bagi sejumlah besar pengguna laporan keuangan dalam membuat keputusan keuangan.Pencatatan semua transaksi keuangan sampai dengan penyusunan laporan keuangan dilakukan dengan menggunakan formulir standar keuangan yang terdiri dari buku kas umum dan buku kas khusus, buku material, rencana penggunaan dana, dan laporan penggunaan dana. Bagi pihak-pihak diluar manajemen suatu perusahaan, laporan keuangan merupakan jendela informasi yang memungkinkan mereka "mengintip" kondisi perusahaan tersebut.

\section{METODE}

Pendekatan Penelitian dipilih dengan mempertimbangkan keserasian dengan objek yang diteliti. Setelah data terkumpul kemudian diklasifikasikan sesuai dengan jenis data, setelah itu dilakukan penyederhanaan data, pengolahan data dan baru kemudian ditarik kesimpulan akhir. Memperhatikan masalah pokok dan tujuan yang ingin dicapai dalam penelitian ini bersifat memberikan pendekatan kualitatif secara menyeluruh yang bertujuan untuk mencari informasi yang aktual sesuai dengan fakta yang terperinci tentang pelaksanaan analisa laporan keuangan produk simpanan pada Koperasi Kredit Bina Masyarakat Sekadau, maka jenis penelitian yang sesuai untuk dipergunakan adalah jenis penelitian deskriptif. Dengan melakukan penelitian ini diharapkan dapat dilakukan berdasarkan faktafakta yang tampak sebagaimana adanya, apa yang dipaparkan berupa penyajian pembahasan sesuai dengan kenyataan yang terjadi pada saat penelitian dilakukan, kemudian dianalisis sehingga hasil penelitian ini hanya berlaku pada daerah penelitian saja. Lokasi penelitian adalah Koperasi Kredit Bina Masyarakat Sekadau. Setelah diolah data dianalisis dengan analisis kualitatif.

\section{HASIL PENELITIAN DAN PEMBAHASAN}

Analisis keuangan adalah suatu analisis ratio keuangan, analisis kelemahan dan kekuatan di bidang finansial di mana analisis ini diperuntukkan dalam menilai prestasi manajemen di masa lalu dan prospeknya di masa akan datang. Untuk melakukan analisis ini dapat dilakukan dengan membandingkan prestasi suatu periode dibanding dengan periode sebelumnya sehingga diketahui adanya kecenderungan selama periode tertentu. Sehubungan dengan penilaian kinerja pada aspek keuangan, maka informasi akuntansi dalam bentuk laporan keuangan banyak memberikan manfaat kepada pengguna apabila laporan tersebut dianalisa lebih lanjut sebelum dimanfaatkan sebagai alat bantu pembuatan keputusan oleh pihak-pihak yang berkepentingan dengan informasi tersebut. Laporan keuangan dalam bentuk dasar seperti neraca dan laporan aliran kas masih belum memberikan manfaat maksimal terhadap usersnya, sebelum pengguna mengolah lebih lanjut dalam bentuk analisa laporan keuangan seperti rasio-rasio keuangan. Analisa laporan keuangan dapat digunakan oleh berbagai pihak untuk memprediksi masa depan dan menilai kinerja sebuah organisasi yang diberi tanggung jawab untuk menjalankan dana yang sudah ditanamkan oleh investor, dalam hal ini pemerintah. Sedangkan bagi manajemen, analisa laporan keuangan digunakan untuk membantu mengantisipasi kondisi dimasa depan, dan yang lebih penting sebagai titik awal untuk merencanakan tindakan yang akan mempengaruhi peristiwa dimasa depan.

Pencatatan transaksi keuangan produk Simpanan diawali pada saat anggota menyetor simpanannya sesuai dengan jenis masing-masing dan diprint out langsung ke dalam buku anggota, setelah itu pegawai membukukan transaksi tersebut kedalam pembukuan Jurnal setiap bulannya. Dengan adanya pencatatan transaksi keuangan setiap bulannya memudahkan Koperasi Kredit 
242 . Fokus, Volume 18, Nomor 2, September 2020, hlm. 237 - 247

Bina Masyarakat Cabang Sekadau dalam melihat perkembangan Koperasi secara kuantitas. Adapun transaksi keuangan produk Simpanan Saham Bulan Juli tahun 2019 dapat dilihat pada tabel 4 berikut.

Tabel 2 Transaksi Keuangan Produk Simpanan Saham Pada Bulan Juli Tahun 2019 Koperasi Kredit Bina Masyarakat Cabang Sekadau

\begin{tabular}{|c|c|c|c|c|c|c}
\hline $\begin{array}{c}\text { Jenis } \\
\text { Simpanan }\end{array}$ & Bulan lalu & Setor & Tarik & $\begin{array}{c}\text { Mutasi } \\
\text { Masuk }\end{array}$ & $\begin{array}{c}\text { Mutasi } \\
\text { Keluar }\end{array}$ & Saldo \\
\hline $\begin{array}{c}\text { Simpanan } \\
\text { Pokok }\end{array}$ & $512,133,000$ & $11,135,000$ & $2,175,000$ & - & 500,000 & $520,593,000$ \\
\hline $\begin{array}{c}\text { Simpanan } \\
\text { Wajib }\end{array}$ & $602,293,800$ & $7,275,000$ & $1,375,000$ & - & 300,000 & $607,893,800$ \\
\hline
\end{tabular}

Sumber : Koperasi Kredit Bina Masyarakat Cabang Sekadau, Juli 2019

Berdasarkan dari tabel 4 diatas, pencatatan transaksi keuangan produk Simpanan Saham terdiri dari 7 (tujuh) kolom, dimulai dari kolom jenis simpanan yang menjelaskan mengenai jenis simpanan saham yang terdiri dari dua yaitu simpanan pokok dan simpanan wajib, selanjutnya kolom keterangan pencatatan bulan lalu dimana untuk simpanan pokok sebesar Rp 512,133,000,(Lima ratus juta dua belas ribu seratus tiga puluh tiga rupiah) dan untuk simpanan wajib sebesar Rp. 602,293,800,- (Enam ratus dua juta dua ratus sembilan puluh tiga delapan ratus rupiah). Kolom Setor yang mencatat mengenai jumlah setoran anggota, dimana untuk simpanan pokok sebesar Rp. 11,135,000,- (sebelas juta seratus tiga puluh lima ribu rupiah), dan simpanan wajib adalah sebesar Rp. 7,275,000,- (tujuh juta dua ratus tujuh puluh lima ribu rupiah). Kolom Tarik yang mencatat mengenai jumlah penarikan anggota, dimana untuk simpanan pokok sebesar Rp. 2,175,000,- (Dua juta seratus tujuh puluh lima ribu rupiah) dan simpanan wajib sebesar $\mathrm{Rp}$ 1,375,000,- (Satu juta tiga ratus tujuh puluh lima ribu rupiah)

Selanjutnya, seperti yang terlihat pada tabel adalah kolom mutasi masuk yang menjelaskan mengenai pencatatan anggota yang pindah lokasi dari cabang lain ke Koperasi Kredit Bina Masyarakat Cabang Sekadau, pada bulan Juni tahun 2019 tidak ada pencatatan pada mutasi masuk. Kolom mutasi keluar yang menjelaskan mengenai pencatatan anggota yang pindah lokasi dari Koperasi Kredit Bina Masyarakat Cabang Sekadau ke cabang lainnya, pada bulan Juni tahun 2019 ada pencatatan mutasi masuk untuk simpanan pokok sebesar Rp. 500,000,- (Lima ratus ribu rupiah) dan untuk simpanan wajib sebesar $\mathrm{Rp}$. $300,000,-$ (Tiga ratus ribu rupiah). Kolom yang terakhir adalah kolom saldo yang menjelaskan mengenai jumlah rincian jumlah simpanan saham bulan Juni ditambah dengan setoran simpanan bulan Juli tahun 2019, dimana untuk simpanan pokok saldonya sebesar Rp. 520,593,000,- (Lima ratus dua puluh juta lima ratus sembilan puluh tiga ribu rupiah), dan untuk simpanan wajib saldonya sebesar Rp. 607,893,800,- (Enam ratus tujuh juta delapan ratus sembilan puluh tiga delapan ratus rupiah).

Untuk melihat transaksi keuangan produk Simpanan Non Saham Bulan Juli tahun 2019 dapat dilihat pada tabel 5 berikut.

Tabel 3 Transaksi Keuangan Produk Simpanan Non Saham Pada Bulan Juli Tahun 2019 Koperasi Kredit Bina Masyarakat Cabang Sekadau

\begin{tabular}{|c|c|c|c|c|c|c}
\hline $\begin{array}{c}\text { Jenis } \\
\text { Simpanan }\end{array}$ & Bulan Lalu & Setor & Tarik & $\begin{array}{c}\text { Mutasi } \\
\text { Masuk }\end{array}$ & $\begin{array}{c}\text { Mutasi } \\
\text { Keluar }\end{array}$ & Saldo \\
\hline SSA & $5,028,885,412$ & $191,239,713$ & $123,637,529$ & - & $14,970,923$ & $5,081,516,673$ \\
\hline SINTAK & $407,087,522$ & $115,715,697$ & $166,791,078$ & & & $356,012,141$ \\
\hline SISUKA & - & & - & - & & - \\
\hline TAWA & $78,169,191$ & $2,858,676$ & 960,000 & - & & $80,067,867$ \\
\hline SIMATU & $41,894,211$ & $1,383,756$ & - & - & & $43,277,967$ \\
\hline SIBUN & $106,893,724$ & $2,009,722$ & $1,100,000$ & - & & $107,803,446$ \\
\hline TUNAS & $235,180,030$ & $20,967,553$ & $16,338,000$ & 136,771 & & $239,946,354$ \\
\hline JUMLAH & $5,898,110,090$ & $334,175,117$ & $308,826,607$ & 136,771 & $14,970,923$ & $5,908,624,448$ \\
\hline \hline
\end{tabular}

Sumber : Koperasi Kredit Bina Masyarakat Cabang Sekadau, Juli 2019

Berdasarkan dari tabel 5 diatas, bahwa pencatatan transaksi keuangan produk Simpanan Non Saham terdiri dari 7 (tujuh) kolom, dimulai dari kolom jenis simpanan yang menjelaskan mengenai jenis simpanan non saham yang terdiri dari 7 (tujuh) jenis simpanan yaitu SSA, SINTAK, SISUKA, TAWA, SIMATU, SIBUN dan TUNAS. Selanjutnya kolom keterangan pencatatan bulan lalu 
Yuliana.F. Lilistian, Analisa Laporan Keuangan Produk Simpanan Pada Koperasi Kredit 243

yang mencatat jumlah saldo bulan lalu atau bulan Juni adalah sebesar Rp. 5,898,110,090,- (Lima miliar delapan ratus sembilan puluh delapan juta seratus sepuluh ribu sembilan puluh rupiah). Kolom Setor yang mencatat mengenai jumlah setoran anggota, terlihat jumlah setoran simpanan non saham pada bulan Juli adalah sebesar Rp 334,175,117,- (tiga ratus tiga puluh empat juta seratus tujuh puluh lima seratus tujuh belas ribu rupiah). Kolom Tarik yang mencatat mengenai jumlah penarikan anggota, dimana jumlah tarikan simpanan non saham adalah sebesar Rp 308,826,607,- (Tiga ratus delapan juta delapan ratus dua puluh enam ribu enam ratus tujuh ribu rupiah). Selanjutnya, seperti yang terlihat pada tabel adalah kolom mutasi masuk yang menjelaskan mengenai pencatatan anggota yang pindah lokasi dari cabang lain ke Koperasi Kredit Bina Masyarakat Cabang Sekadau, pada bulan Juni tahun 2019 ada pencatatan pada mutasi masuk sebesar Rp 136,771,-(Seratus tiga puluh enam ribu tujuh ratus tujuh puluh satu ribu rupiah).

Kolom mutasi keluar, menjelaskan mengenai pencatatan anggota yang pindah lokasi dari Koperasi Kredit Bina Masyarakat Cabang Sekadau ke cabang lainnya, pada bulan Juni tahun 2019 ada pencatatan mutasi masuk sebesar Rp. 14,970,923,- (Empat belas juta sembilan ratus tujuh puluh ribu sembilan ratus dua puluh tiga ribu rupiah). Kolom yang terakhir adalah kolom saldo yang menjelaskan mengenai jumlah rincian jumlah simpanan saham bulan Juni ditambah dengan setoran simpanan bulan Juli tahun 2019 ditambah dengan mutasi masuk dikurangi dengan mutasi keluar dan tarik sehingga menghasilkan saldo sebesar Rp. 5,908,624,448,- (Lima milyar sembilan ratus delapan juta enam ratus dua puluh empat ribu empat ratus empat puluh delapan ribu rupiah). Berdasarkan dari hasil observasi terlihat bahwa pada Koperasi Kredit Bina Masyarakat Cabang Sekadau sudah dilakukan pencatatan transaksi keuangan produk simpanan. Bagian keuangan mencatat dan membukukan transaksi keuangan yang dilakukan setiap bulannya. Salah satu faktor yang sangat menentukan suatu perusahaan atau koperasi berkembang dengan baik adalah kebijaksanaan di bidang keuangan. Semua pihak yang berkepentingan terhadap suatu badan usaha sangat perlu mengetahui kondisi keuangannya. Kondisi keuangan dapat diketahui dengan menilai laporan keuangan yang telah disusun oleh badan usaha yang bersangkutan dari suatu periode tertentu. Laporan keuangan merupakan salah satu informasi yang diperlukan pimpinan-pimpinan perusahaan untuk mengetahui tentang kekayaan dan kewajiban serta perubahan netto dari kekayaan hasil aktivitas koperasi. Analisis terhadap data keuangan dari koperasi yang bersangkutan diperlukan untuk memperoleh gambaran tentang hasil atau perkembangan usaha koperasi. Data keuangan tersebut akan tercermin didalam laporan keuangan yang terdiri dari neraca, laporan laba rugi atau laporan sisa hasil usaha serta laporan keuangan yang lain.

Akuntansi merupakan suatu aktivitas jasa yang berfungsi menyediakan informasi kuantitatif tentang kondisi keuangan dan hasil operasi perusahaan yang diharapkan bermanfaat dalam pengambilan keputusan ekonomi. Dalam akuntansi keuangan, informasi itu disusun dalam bentuk laporan-laporan yang menunjukkan posisi keuangan dan hasil usaha perusahaan untuk periode tertentu. Laporan keuangan koperasi adalah laporan keuangan yang disusun untuk dapat menggambarkan posisi keuangan, sisa hasil usaha dan arus kas perusahaan secara keseluruhan sebagai pertanggungjawaban pengurus atas pengelolaan keuangan yang ditujukan kepada anggota. Laporan keuangan koperasi disusun untuk mencerminkan posisi keuangan pada tanggal tertentu, hasil usaha dan arus kas koperasi selama periode tertentu. Laporan keuangan setiap entitas akuntansi dalam badan usaha koperasi harus disusun dengan menggunakan kebijakan, sistem dan prosedur akuntansi yang sama. Analisa Aktiva dan pertambahan modal adalah salah satu cara untuk menghitung dan menginterpretasikan rasio keuangan untuk menganalisa dan melihat efektifitas produk simpanan digunakan dengan tepat sasaran dan efisien.

Analisa Aktiva dan pertambahan modal dilakukan secara Time-Series Analysis, artinya Koperasi Kredit Bina Masyarakat Cabang Sekadau melakukan evaluasi atas melalui analisis rasio keuangan likuiditas dan profitabilitas. Rasio Likuiditas adalah rasio yang mengukur kemampuan Koperasi Kredit Bina Masyarakat Cabang Sekadau dalam melihat perkembangan asset. Rasio Likuiditas merupakan indikator yang baik apakah Koperasi Kredit Bina Masyarakat Cabang Sekadau memiliki masalah dalam arus kas atau tidak. Ukuran yangddigunakan adalah Current ratio (CR) dan Quick (Acid-Test) Ratio (QR). Sementara itu, rasio profitabilitas adalah rasio yang mengukur kemampuan anggota Koperasi Kredit Bina Masyarakat Cabang Sekadau dalam menyetorkan produk simpanan. Rasio Profitabilitas merupakan indikator yang baik untuk mengetahui apakah anggota Koperasi Kredit Bina Masyarakat Cabang Sekadau memiliki masalah penyetoran produk simpanan. Ukuran yang digunakan adalah Return On Asset (Pengukuran penyetoran produk simpanan) dan Return On Investment (Perputaran penyetoran produk simpanan) 
Untuk melihat berapa besar analisa rasio keuangan likuiditas produk Simpanan pada Koperasi Kredit Bina Masyarakat Cabang Sekadau dapat dilihat pada tabel 4 berikut.

Tabel 4 Analisa Rasio Keuangan Likuiditas Produk Simpanan Pada Bulan Juli Tahun 2019 Koperasi Kredit Bina Masyarakat Cabang Sekadau

\begin{tabular}{|c|c|c|c|c|}
\hline No & $\begin{array}{l}\text { Rasio } \\
\text { Likuiditas }\end{array}$ & Perhitungan & Indikator & Keterangan \\
\hline 1. & Current Ratio & $\begin{array}{l}\text { A. Simpanan Saham } \\
=\frac{\text { Total Dana Simpanan }}{\text { Saldo simpanan bulan yang berjalan }} \\
=\frac{\text { Rp. } 1,128,486,800,-}{\text { Rp. } 1,114,426,800,-}=1,01 \\
\text { B. Simpanan Non Saham } \\
=\frac{\text { Total Dana Simpanan }}{\text { Saldo simpanan bulan yang berjalan }} \\
=\underline{\text { Rp. } 5,908,624,448,-}=1,00 \\
\text { Rp. } 5,898,110,090,-\end{array}$ & $\begin{array}{l}>1 \text { : buruk } \\
<1: \text { baik }\end{array}$ & Baik \\
\hline 2. & Quick Ratio & $\begin{array}{l}\text { A. Simpanan Saham } \\
=\frac{\text { Total Dana Simp. }- \text { Saldo Mutasi }}{\text { Saldo Simpanan bulan yang berjalan }} \\
=\frac{\text { Rp. } 1,128,486,800-\text { Rp. } 800,000}{\text { Rp. } 1,114,426,800} \\
=1,01 \quad \\
\text { B. Simpanan Non Saham } \\
=\frac{\text { Total Dana Simp. - Saldo Mutasi }}{\text { Saldo simpanan bulan yang berjalan }} \\
=\frac{\text { Rp. } 5,908,624,448-\text { Rp. } 136,771}{\text { Rp. } 5,898,110,090} \\
=1,00\end{array}$ & $\begin{array}{l}>1 \text { :buruk } \\
<1 \text { baik }\end{array}$ & Baik \\
\hline
\end{tabular}

Sumber : Data Olahan Koperasi Kredit Bina Masyarakat Cabang Sekadau, Juli 2019

Berdasarkan dari tabel 4 diatas terlihat bahwa Rasio Likuiditas pada Koperasi Kredit Bina Masyarakat Cabang Sekadau, untuk Current Ratio dari indikator menunjukkan bahwa $>1$ (lebih dari 1) rasionya baik, maka dari perhitungan diperoleh nilainya sebesar 1,01 maka CR Simpanan Saham Koperasi Kredit Bina Masyarakat Cabang Sekadau adalah baik. Selanjutnya, untuk Current Ratio dari indikator menunjukkan bahwa $>1$ (lebih dari 1) rasionya baik, maka dari perhitungan diperoleh nilainya sebesar 1,00 maka CR Simpanan Non Saham Koperasi Kredit Bina Masyarakat Cabang Sekadau adalah baik.
Qiuck Ratio pada Koperasi Kredit Bina Masyarakat Cabang Sekadau, dari indikator menunjukkan bahwa > 1 (lebih dari 1) rasionya baik, maka dari perhitungan diperoleh nilainya sebesar 1,01 maka QR Simpanan Saham Koperasi Kredit Bina Masyarakat Cabang Sekadau adalah baik. Selanjutnya, untuk Qiuck Ratio pada Koperasi Kredit Bina Masyarakat Cabang Sekadau, dari indikator menunjukkan bahwa $>1$ (lebih dari 1) rasionya baik, maka dari perhitungan diperoleh nilainya sebesar 1,00 maka QR Simpanan Non Saham Koperasi Kredit Bina Masyarakat Cabang Sekadau adalah baik. 
Yuliana.F. Lilistian, Analisa Laporan Keuangan Produk Simpanan Pada Koperasi Kredit 245

Aktiva adalah sumber daya yang dikuasai oleh badan usaha koperasi yang diperoleh dari transaksi atau kejadian masa lalu, yang memberikan manfaat ekonomi dimasa depan. Aktiva disajikan dalam neraca berdasarkan urutan likuiditas, dimulai dari yang paling likuid sampai kepada aktiva yang tidak likuid. Untuk melihat berapa besar analisa rasio keuangan profitabilitas produk Simpanan pada Koperasi Kredit Bina Masyarakat Cabang Sekadau dapat dilihat pada tabel 5 berikut.

Tabel 5 Analisa Rasio Keuangan Profitabilitas Produk Simpanan Pada Koperasi Kredit Bina Masyarakat Cabang Sekadau

\begin{tabular}{|c|c|c|c|c|}
\hline No & Rasio Aktivitas & Perhitungan & Indikator & Keterangan \\
\hline 1. & $\begin{array}{l}\text { Return On Assets }( \\
\text { ROA })\end{array}$ & $\begin{array}{l}\text { A. Simpanan Saham } \\
=\underline{\text { Jumlah Tarikan Simpanan }} \\
\text { Jumlah Setoran Simpanan } \\
=\text { Rp. } 3,550,000,-- \text { x } 100 \% \\
\text { Rp. } 18,410,000,- \\
=19,28 \% \\
\text { B. Simpanan Non Saham } \\
=\underline{\text { Jumlah Tarikan Simpanan }} \\
\text { Jumlah Setoran Simpanan } \\
=\underline{\text { Rp. } 308,826,607,--} \text { x } 100 \% \\
\begin{array}{l}\text { Rp. } 334,175,117,- \\
=92,41 \%\end{array}\end{array}$ & $\begin{array}{l}>10 \% \text { : baik } \\
<10 \% \text { : buruk }\end{array}$ & Baik \\
\hline 2. & $\begin{array}{l}\text { Return On Investment } \\
(\mathrm{ROE})\end{array}$ & $\begin{array}{l}\text { A. Simpanan Saham } \\
=\text { Jumlah Setoran Simpanan } \\
\text { Saldo Simpanan bulan } \\
\text { berjalan } \\
=\underline{\text { Rp. } 18,410,000,--} \\
\text { Rp. 1,128,486,800,- } \\
=1,63 \\
\text { B. Simpanan Non Saham } \\
=\frac{\text { Jumlah Setoran Simpanan }}{\text { Saldo Simpanan bulan }} \\
\text { berjalan } \\
=\frac{\text { Rp. } 334,175,117,-}{\text { Rp. } 5,908,624,448,-} \\
=5,65\end{array}$ & $\begin{array}{l}>1 \text { : baik } \\
<1 \text { : buruk }\end{array}$ & Baik \\
\hline
\end{tabular}

Sumber : Data Olahan Koperasi Kredit Bina Masyarakat Cabang Sekadau, Juli 2019

Berdasarkan dari tabel 5 diatas terlihat bahwa Rasio Profitabilitas, untuk Return On Assets (ROA) dari indikator yang menunjukkan bahwa $>10 \%$ (lebih dari $10 \%$ ) rasionya baik, maka dari perhitungan diperoleh nilainya sebesar 19,28\% maka ROA produk simpanan saham pada Koperasi Kredit Bina Masyarakat Cabang Sekadau adalah baik. Selanjutnya, untuk Return On Assets (ROA) dari indikator yang menunjukkan bahwa $>10 \%$ (lebih dari $10 \%$ ) rasionya baik, maka dari perhitungan diperoleh nilainya sebesar 92,41\% maka ROA produk simpanan saham pada Koperasi Kredit Bina Masyarakat Cabang Sekadau adalah baik. Return On Investment (ROE) dari indikator yang menunjukkan bahwa $>1$ (lebih dari 1 ) rasionya baik, maka dari perhitungan diperoleh nilainya sebesar 1,63 maka ROE produk simpanan non saham pada Koperasi Kredit Bina Masyarakat Cabang Sekadau adalah baik. Selanjutnya, Return On Investment (ROE) dari indikator yang menunjukkan bahwa $>1$ (lebih dari 1 ) rasionya baik, maka dari perhitungan diperoleh nilainya sebesar 5,65 maka ROE produk simpanan non saham pada Koperasi Kredit Bina Masyarakat Cabang Sekadau adalah baik.

Analisa laporan keuangan produk simpanan dari segi analisis aktiva dan pertambahan modal memberikan indikator baik karena Koperasi Kredit Bina Masyarakat Cabang Sekadau mampu menganalisis rasio likuiditas dan rasio profitabilitas 
dengan produk simpanan saham dan non saham. Bentuk analisa aktiva dan pertambahan modal pada laporan keuangan Koperasi Kredit Bina Masyarakat Cabang Sekadau adalah dengan mengunakan buku kas umum, pencatatan transaksi-transaksi dari buku kas umum dengan tujuan pihak manajemen mengetahui berbagai bentuk keuangan sehingga mempermudah dalam kegiatan pencatatan laporan keuangan koperasi. Koperasi Kredit Bina Masyarakat Cabang Sekadau sudah melakukan analisis laporan keuangan produk simpanan dari segi analisis aktiva dan pertambahan modal dan memberikan indikator baik. Caranya adalah menghitung dengan menggunakan analisis rasio likuiditas dan profitabilitas dengan mengunakan buku kas umum, pencatatan transaksi-transaksi dari buku kas umum dengan tujuan agar pihak manajemen Koperasi Kredit Bina Masyarakat Cabang Sekadau mengetahui berbagai bentuk keuangan sehingga mempermudah dalam menghitung produk simpanan.

Pengelolaan keuangan program dilakukan Koperasi Kredit Bina Masyarakat Cabang Sekadau mengikuti sistem dan prosedur akuntansi pemerintah. Caranya adalah dengan melakukan Perhitungan hasil sisa usaha yang menyajikan hasil akhir yang disebut sisa hasil usaha. Sisa hasil usaha yang diperoleh mencakup hasil usaha anggota dan laba atau rugi kotor dengan non anggota. Perhitungan hasil sisa usaha menyangkut manfaat dari usaha koperasi tidak semata-mata diukur dari sisa hasil usaha atau laba tetapi ditentukan pada manfaat bagi anggota. Laporan perhitungan hasil usaha disajikan dengan memisahkan perkiraan pendapatan dan beban yang berasal dari kegiatan yang diselenggarakan untuk anggota dan non anggota. Koperasi Kredit Bina Masyarakat Cabang Sekadau sudah melakukan pelaporan keuangan produk simpanan saham dan simpanan non saham. Cara pelaporan keuangan produk simpanan adalah dengan mengunakan data yang sesuai dengan pencatatan transaksi keuangan, buku kas umum, neraca dan saldo akhir, dan perhitungan sisa hasil usaha dalam rapat anggota sebagai lembaga tertinggi. Ada beberapa aspek yang harus diperhatikan dalam pelaporan keuangan produk simpanan, yaitu sebagai berikut : Buku kas Umum, Kartu kredit anggota, neraca akhir, saldo akhir, modal awal, dan berapa jumlah keuangan yang dikelola.Berdasarkan dari hasil observasi terlihat bahwa pada Koperasi Kredit Bina Masyarakat Cabang Sekadau sudah membuat laporan keuangan produk simpanan saham dan non saham yang dilaporkan pada setiap bulannya. Laporan tersebut menampakkan transparansi produk simpanan saham dan non saham yang dilakukan oleh anggota sehingga nantinya dapat dipertanggungjawabkan kembali kepada anggota.

\section{KESIMPULAN DAN SARAN}

Pencatatan transaksi keuangan produk Simpanan diawali pada saat anggota menyetor simpanannya sesuai dengan jenis masing-masing dan diprint out langsung ke dalam buku anggota, setelah itu pegawai membukukan transaksi tersebut kedalam pembukuan Jurnal setiap bulannya. Analisa Aktiva dan pertambahan modal dilakukan secara Time-Series Analysis, artinya Koperasi Kredit Bina Masyarakat Cabang Sekadau melakukan evaluasi atas melalui analisis rasio keuangan likuiditas dan profitabilitas yang hasilnya memberikan indikator baik. Cara pelaporan keuangan produk simpanan adalah dengan mengunakan data yang sesuai dengan pencatatan transaksi keuangan, buku kas umum, neraca dan saldo akhir, dan perhitungan sisa hasil usaha dalam rapat anggota sebagai lembaga tertinggi. Dari beberapa kesimpulan diatas, maka penulis memberikan saran sebagai berikut : tetap mempertahankan analisa laporan keuangan yang telah ada selama ini dengan menjaga rasio likuiditas dan rasio profitabilita dengan indikator baik serta melaporkan kepada manajemen tingkat atas laporan keuangan produk simpanan yang dikelola setiap bulannya sehingga akuntabilitas.

\section{DAFTAR PUSTAKA}

Arikunto, S. 2010. Prosedur Penelitian, Suatu Pendekatan Praktek. Jakarta: PT. Rineka Cipta.

Credit Union Keling Kumang. 2014. Pola Kebijakan Credit Union Keling Kumang Tahun Buku 2014. Sintang: CU KK.

Jumingan, 2011. Analisis Laporan Keuangan. Jakarta: PT. Bumi Aksara

Moleong, Lexy J. 2008. Metodologi Penelitian Kualitatif. Terjemahan oleh Tjun Surjaman. Bandung : PT Remaja Rosdakarya.

Nawawi, H. 2001. Metode Penelitian Bidang Sosial. Yogyakarta: Gadjah Mada Press

Niswonger, C. Rollin, dkk. 1999. Prinsip-Prinsip Akuntansi, Edisi 19 Jilid 1. Jakarta: Penerbit Erlangga.

Peraturan Pemerintah Nomor 9 Tahun 1995 tentang Pelaksanaan Kegiatan Usaha Simpan Pinjam oleh Koperasi. Jakarta: $\mathrm{PP}$ 
Yuliana.F. Lilistian, Analisa Laporan Keuangan Produk Simpanan Pada Koperasi Kredit 247

Santoso, G. 2005. Metodologi Penelitian. Jakarta: Prestasi Pustaka.

Sartono, Agus. 2001. Manajemen Keuangan, Edisi ke-empat. Yogyakarta: BPFE.

Siagian, S.P. 2006. Manajemen Sumber Daya Manusia. Jakarta: Bumi Aksara.

Sitio, Arifin, dkk. 2001. Koperasi: Teori dan Praktik. Jakarta: PT. Erlangga.

Soemarso, S. R. 2004. Akuntansi Suatu Pengantar, Edisi 5 Buku 1. Jakarta: Salemba Empat.

Sukamdiyo. 1996. Manajemen Koperasi. Semarang: Fakultas Ekonomi Universitas Diponegoro.
Sugiyono. 2007. Metode Penelitian Kuantitatif, Kualitatif dan $R \& D$. Jakarta: CV. Alfabeta

Undang-Undang Nomor 17 Tahun 2012 Tentang Perkoperasian. Jakarta: UU.

Veithzal, Rival.2010. Manajemen Sumber Daya Insani Untuk Perusahaan: Dari Teori Ke Praktik. Jakarta: Rajawali pers.

Wexley Kenneth N \& Yulk Gary.2000. Perilaku Organisasi dan Psikologi Personalia. Jakarta: PT. Rineka Cipta.

Widiyanti, Ninik. 2002. Manajemen Koperasi. Jakarta: Rineka Cipta.

Woeryanto,H. 2003. Koperasi Kredit Untuk Anda, Edisi I. Jakarta: Yayasan Bekatiga Indonesia. 